\title{
Theories and Methods for the Study of Multilevel Environmental Governance
}

Moeko Saito-Jensen

Project Guide and Methods Training Manual. Guideline. Bogor, Indonesia: CIFOR.

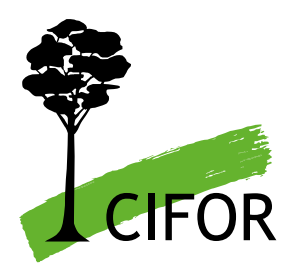


Guideline

(c) 2015 Center for International Forestry Research

(c) (i) Content in this publication is licensed under a Creative Commons Attribution 4.0 International (CC BY 4.0), http://creativecommons.org/licenses/by/4.0/

ISBN 978-602-1504-87-1

DOI: $10.17528 /$ cifor/005541

Saito-Jensen M. 2015. Theories and Methods for the Study of Multilevel Environmental Governance. Guideline. Bogor, Indonesia: CIFOR.

Corresponding author Ashwin Ravikumar - ashwin.r@cgiar.org

CIFOR

J. CIFOR, Situ Gede

Bogor Barat, 16115

Indonesia

$\mathrm{T}+62(251) 8622-622$

$\mathrm{F}+62(251) 8622-100$

E cifor@cgiar.org

\section{cifor.org}

We would like to thank all donors who supported this research through their contributions to the CGIAR Fund. For a list of Fund donors please see: https://www.cgiarfund.org/FundDonors

Any views expressed in this publication are those of the authors. They do not necessarily represent the views of CIFOR, the editors, the authors' institutions, the financial sponsors or the reviewers. 


\section{Contents}

Note to the reader iv

Introduction 1

MultiLevel Governance Theory 2

Democracy, Accountability and Civil Society $\quad 7$

Governmentality and Environmentality $\quad 12$

Co-Producing Government and Society 16

Summary: Theories and Methods for Studying Environmental Governance 19

$\begin{array}{ll}\text { Bibliography } & 23\end{array}$

$\begin{array}{ll}\text { Endnotes } & 27\end{array}$ 


\section{Note to the reader}

This critical review was commissioned by the governance team that is coordinating research on multilevel governance and carbon management at the landscape scale, as part of CIFOR's Global Comparative Study on REDD+. The review is fundamental to our understanding of multilevel governance and to the approach we chose to take in the organization of the research. It was used to facilitate discussion and debate, some of which is captured in endnotes that we have chosen to keep in the text.

This article should be used in conjunction with the other methodological tools provided in this folder, which include our interview questionnaires and research guide, as well as the NVIVO coding tree used to code the data. This coding tree may be updated over time. 



\section{Introduction}

The CIFOR project "multilevel governance and REDD+" has two central goals "1) to identify options for the design of governance institutions and organizations for the development of a just and transparent benefit sharing systems; and 2) to improve the design of multiple level institutions and processes to overcome economic and policy barriers to REDD+ implementation and other low carbon land use options". In line with these goals, the objective of this review is to provide input for a "theoretically grounded framework for the study of multi level governance and REDD+ through the review of theory and methods of direct relevance to MLG especially with regard to benefit sharing mechanisms and land use decisions"."

In the following, I review in detail several analytical approaches that hold potential relevance for the attainment of the CIFOR research goals. Given the project emphasis on governance at multiple levels, I begin by examining the literature, on multilevel governance theory (MLG) coming out of political science. Though this theoretical agenda is fairly comprehensive, it also has limitations, both in terms of its analytical assumptions and its methodological orientation. In later sections, I therefore turn to other bodies of literature, with a view to strengthening CIFOR's capacity to understand and address the challenges of designing governance systems for the development of transparent benefit sharing systems and overcoming barriers to REDD+ implementation. In the second section, I review the literature on state-society relations, with a particular emphasis on democracy, accountability and civil society, which has emerged from varied social science traditions including political ecology and social studies of natural resource management. In the third section on governmentality and environmentality, I discuss a body of mainly anthropological literature on development and the environment, which is particularly influenced by Michel Foucault's seminal analyses of power and government. ${ }^{2}$ Finally, in the fourth section, I review recent arguments about the co-production of knowledge, government and society, which has emerged from the field of science and technology studies.

These are very different approaches, which embody different assumptions of what governance and society is, what their potential relations might be, how these relations might be studied, and what the outcome of such studies might be. In conclusion, I return to the question of defining a theoretically grounded framework for engaging the multilevel governance and REDD+ project's central questions. Though interesting ideas and lessons are to be found in all of the approaches I examine, there are also important epistemological, methodological and analytical choices to be made. Hence, I do not believe that the framework to be developed will be enhanced by drawing eclectically on all of the ideas I review below. 


\section{Multilevel Governance Theory}

The term multilevel governance (MLG) was developed by the political scientist Gary Marks (1993). The concept aimed in particular to capture and understand political processes related to the emergence of supranational institutions such as the European Union and to facilitate analysis of decentralized decision-making processes, in which sub-national level governments and civil society have come to have increasing influence. As the word, "multilevel" suggests, the concept of MLG comprises numerous state and non-state actors located at different levels, such as the local (sub-national), the national and the global (supranational). The challenge pinpointed by MLG theorists is that these diverse levels of government must somehow be aligned to enable the definition of collective goals (Bache and Flinders 2004, Betsill and Bulkeley 2006, Bulkeley et al. 2003).

According to MLG theory, states are no longer the monopolizing or even necessarily central actors of policymaking. Instead, the power of government is increasingly shaped by and shared between actors operating at multiple levels. As a consequence of this development, "the role of the state is being transformed as state actors develop new strategies of coordination, steering and networking that may protect and, in some cases, enhance state autonomy" (Bache and Flinders 2004). The general starting point of MLG theory is therefore that we are witness to a series of reconfigurations of the relationships and modes of interactions between states and other levels of government. This poses the challenge of specifying new mechanisms of control and accountability between such governmental bodies.
From this point of view, REDD+ governance can be characterized as a type of MLG. For example, REDD+ governance involves supranational governance facilitated by global level institutions such as the World Bank's Forest Carbon Partnership Facility (FCPF) and United Nations (UN)-REDD. Nationally, the governments of developing countries are seen to play an important role in implementing diverse policy measures in order to reduce rates of deforestation and forest degradation. However the achievement of this task is also recognized to require the active participation of subnational state and nonstate actors such as involved industries and, especially, the communities that actually manage and use forests. In this section, I discuss how theories related to MLG can help conceptualize REDD+ governance processes. At the end of the section, I indicate some of limitations of this framework.

Hooghe and Marks (2001) argued that theories of multilevel governance can be classified as two distinct types, though they did not see these types as mutually exclusive. The first type of MLG refers to governance with a clear structure and a vertically tiered hierarchy, in which only a limited number of authorities have actual decision-making powers (Fairbrass and Jordan 2001). This analysis of MLG focuses largely upon interactions between different levels of governance and their policy outcomes. From the point of view of this approach, national states retain the central role in defining collective goals. Even so, local governments and non-state actors are viewed as having varying degrees of agency and ability to influence policy-making. For example, lower levels of governance 


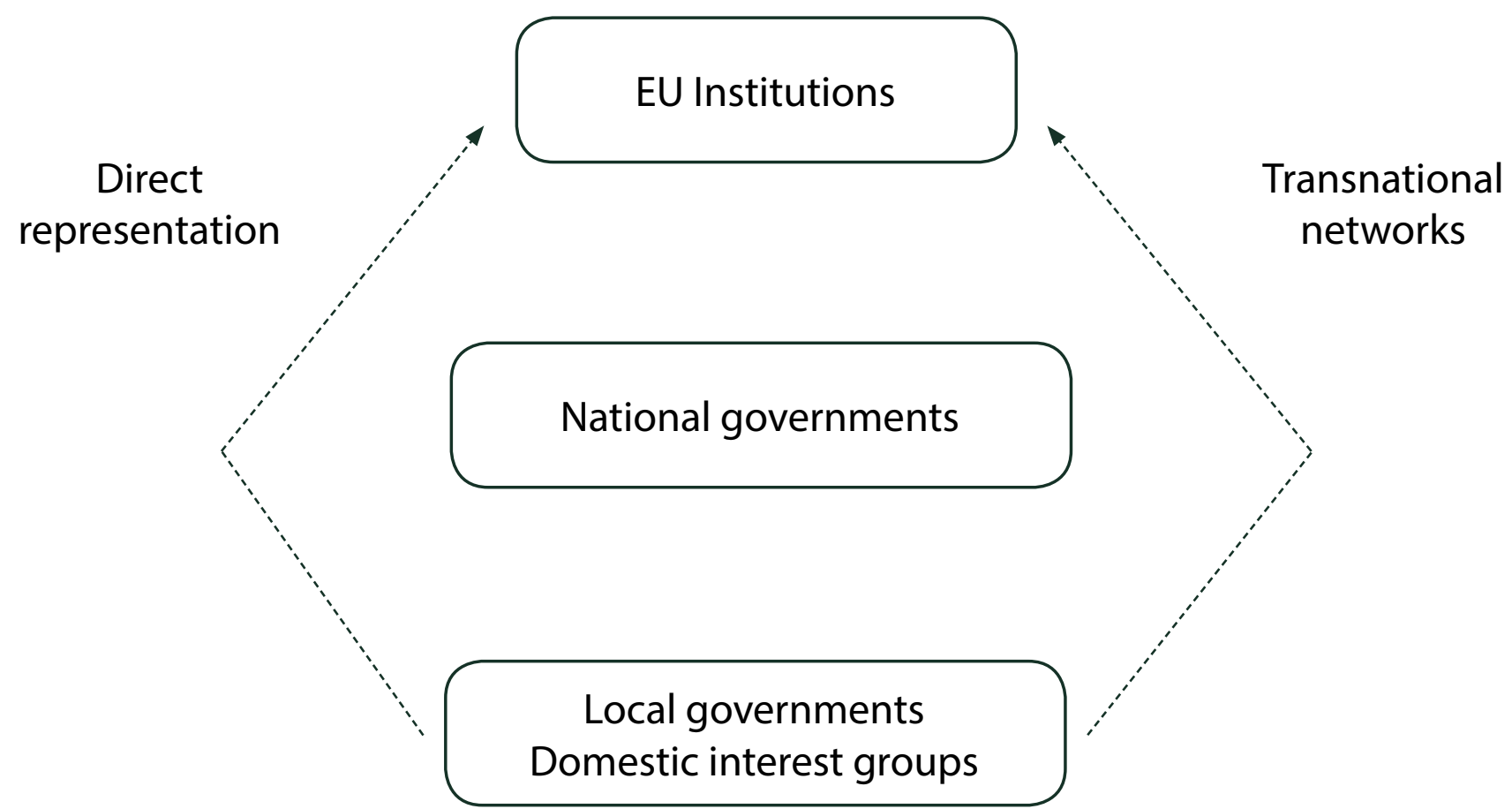

Figure 1. 'Type I' (nested) multilevel governance (adapted from Fairbrass \& Jordan 2001, p. 501).

This figure is extracted from Bulkeley et al. 2003.

may be able to by-pass the decision-making processes at the national level by defining problems in local terms. Or, they might make effective alliances at the global level, again avoiding the national level. However, no matter this flexibility, these levels of governance remain dependent on national level governance, since it is the governmental frameworks of nation states that create the very opportunities to bypass the national level, either by localizing or globalizing decisions (Bulkeley et al. 2003).

The second type of MLG is referred to as "polycentric" and is largely inspired by the work of Vincent and Elinor Ostrom. In contrast with the hierarchical model, Elinor Ostrom $(2010,552)$ characterized polycentric governance as "multiple governing authorities at different scale rather than a monocentric unit". The central point for polycentric MLG is that the clear structures and hierarchies assumed in the previous model are blurred, or even disappear completely, due to the interactions among different governing bodies and actors. Indeed, this blurring occurs not only between different "levels" of governance, but also between different forms of governance, such as state and non-state (Bulkeley 2003). Rather than clearly defined levels, "polycentric" MLG therefore operate with concepts such as "spheres of authority" (Rosenau 1997) or "complex overlapping networks" (Bache and Flinders 2004), which are constituted, or emerge, in situations where territorial or non-territorial based networks negotiate, collaborate or disagree on agendas and decisions (Bulkeley 2003).

Finally, though not directly a part of multilevel governance, it is worth remarking on the recently proposed research framework for earth system governance (Biermann et al. 2010). Earth system governance is defined as the "interrelated and increasingly integrated system of formal and informal rules, rule-making systems, and actor-networks at all levels of human society (from local to global) that are set up to steer societies towards preventing, mitigating, and adapting to global and local environmental change and, in particular, earth system transformation, within the normative context of sustainable development" 


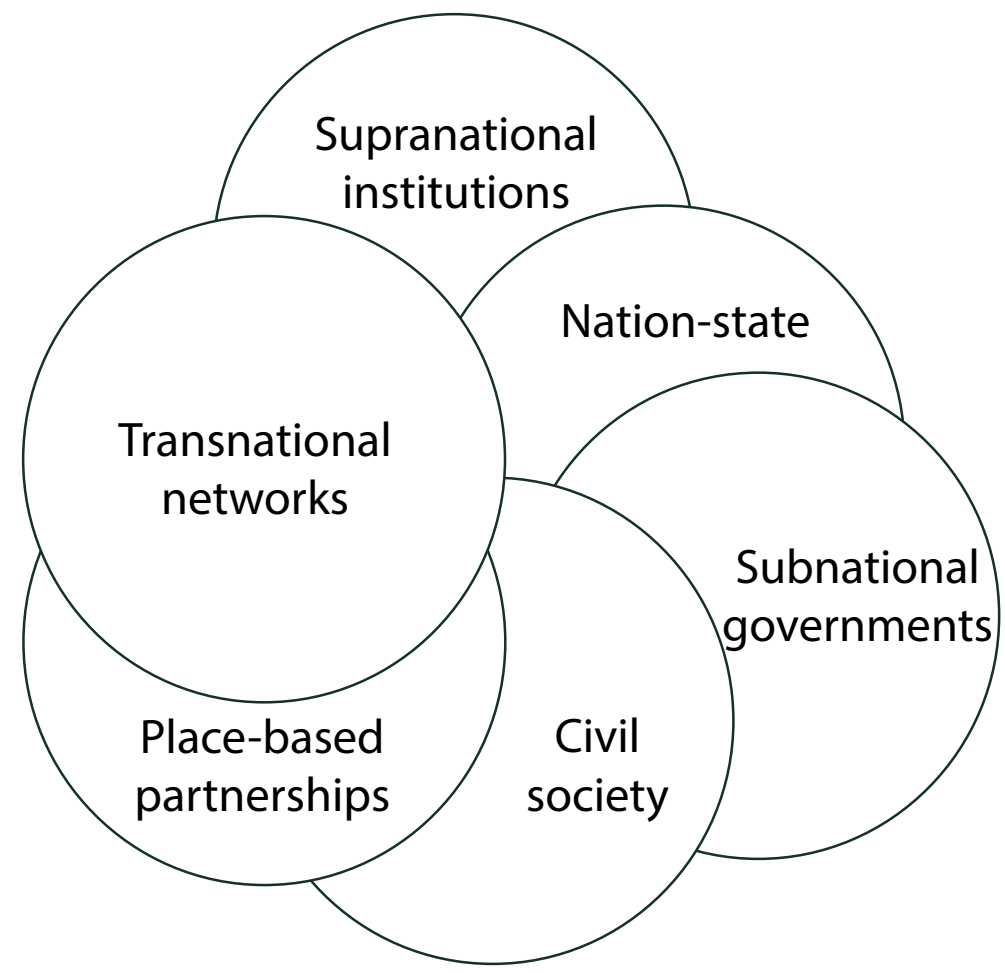

Figure 2. 'Type II' (polycentric) multilevel governance.

This figure is extracted from Bulkeley et al. 2003.

(Biermann et al. 2010, 279). This definition is so encompassing that it might cover almost any aspect of environmental governance and action, from village boards to international agreements. Accordingly, the research framework covers not only the interests of MLG (formal rules and complex interrelations between levels of formal governance) but also of anthropologists of development and social scientists, such as those I discuss in later sections, who analyze processes and outcomes of natural resource management. Due to its comprehensive scope, earth system governance is necessarily abstract and difficult to operationalize. Further, because it draws on multiple sources of social theory, the epistemological and methodological presuppositions of the framework appear eclectic, if not incoherent. ${ }^{3}$ In fact, as I continue to discuss, the analytical assumptions of MLG theory have already been criticized from the point of more culturally and historically sensitive social science approaches.

Before turning to these critiques, let me briefly summarize what we have learned about MLG so far. In spite of differences, the two approaches to MLG share several features. In general, they agree that the role of the state is diminishing, or certainly changing, as various levels of governance interfere with its powers. While state agents retain certain amounts of control, the power to make decisions is transferred in multiple directions, upwards, downwards and sideways, with somewhat unpredictable consequences. This situation creates simultaneous problems and opportunities for effective state governance. On the one hand, problems relate to the aforementioned diminished capacity of states to actually control governance. On the other hand, the fact that the arenas of governance are multiplying also means that states have better possibilities for delegating responsibilities to other levels of governance, which may enable states to effectively target their resources on the particular issues and projects they consider important. As well, state level government is enabled to mobilize and draw upon the resources of actors at other levels, including non-state governance bodies, in trying to achieve their objectives. 
Another general observation of the MLG literature is the increasing importance of mobilization at the subnational governance level. The effectiveness of such mobilization seems most effective when subnational levels of governance create strong connections with civil society organizations. The reason for this increased effectiveness is that lower levels of government can more easily gain the attention and interest of national governing bodies if they can convincingly demonstrate that they have forged strong links with local civil society organizations and are able thereby to claim that they represent the interests of these organizations. Hay (2004, 235-238) refers to this process with the term dual convergence. This notion is used to describe situations within the complex territories of multilevel governance, in which subnational authorities end up promoting local (and thus relatively narrow) interests through lobbying activities: in that sense they may come to operate as extensions of civil society agendas not of their own making. At the same time, however, NGOs and social movements invariably come to take over some of the governing responsibilities previously located squarely in the hands of official subnational governing bodies. In other words, it is as if civil society "seeps into" lower levels of governance through new routes, while simultaneously state governance "seeps into" civil society too. Attentiveness to this increasing complexity and hybridization of governance is one of the central benefits of current MLG thinking. Even so, MLG theory suffers from a number of recognized weaknesses, which falls into two broad groups. The first and most important is the epistemological and methodological presuppositions of MLG. The second is the limited empirical engagement of these approaches with systems of governance that have evolved outside the highly regulated zones of the EU and the US.

In his review of MLG theory from the point of view of the challenges of governance in South East Europe, Paul Stubbs (2005) discusses both of these problems. As regards the epistemology of MLG, Stubbs notes that the literature is dominated by a "peculiar 'realist modernism' untouched by the 'cultural turn' in much of the social sciences" (Stubbs 2005, 66) and in particular of the work of Michel Foucault (to which I return in the later section on governmentality). Inspired by this literature, Stubbs identifies what he views as the three central problems with MLG: "premature normativism", "abstract modelling" and "rehashed neo-pluralism".

By premature normativism, Stubbs points to the tendency in the MLG literature to surreptitiously shift between the scientific task of understanding "how" MLG works, to the policy oriented task of evaluating "how well" it works. Doing so, MLG-theorists take for granted governance should in fact become multijurisdictional, without critically analyzing the implications of this change.

The problem of abstract modeling exacerbates this problem. Theoretical modeling, Stubbs argues, is a dominant preoccupation in much mainstream political science. However, the modeling of multilevel governance relies on assumptions, often unstated, of the elements that make up governance relations. Further, Stubbs suggests, such models, though they can certainly be heuristically useful, are inherently reductive, since the multiple dimensions of empirical reality are reduced to a limited set of variables.

Thus there is an inherent tension between the theoretical models of multilevel governance and specific cases of governance, especially cases that are radically different from the ones used to model MLG theory in the first place. Thus, Stubbs argues that MLG theories and analytical frameworks that were originally developed primarily to analyze Western European governance runs into a series of empirical and conceptual difficulties in the context of South East European governance. For example, the assumption that governance is a way of balancing competing interest groups is hard to square with the "complexities and paradoxes of 'failed', 'weak', 'authoritarian"' (Stubbs 2005, 73) states in South East Europe. How does "the broadly consensual notion of multilevel governance, framed in terms of technical questions of 'co-ordination"' (Stubbs 2005, 73) asks Stubbs, allow analysts to deal with war torn countries, 'neo-protectorates', dictatorships and the like? Similar questions may well also arise when MLG is applied in other contexts, whose governance contexts do not resemble Western Europe or the US. 
Thus, Stubbs refers to MLG as a kind of "rehashed neopluralism". By this he means that MLG is premised on a basically liberal, pluralist and consensual understanding of the distribution of power in society. The problem is that issues of power, stratification, and contestation are rendered invisible from such a perspective. Governance, even if conducted at multiple levels, is seen as ideally unfolding as the "coherent implementations of a unified discourse and plan" (Stubbs 2005, 72, citing Clarke 2004, 94). What capacity, asks Stubbs, does MLG have for dealing with the "paradoxes, tensions and incompatibilities" of governance? This critical question is especially relevant if one thinks of applying MLG in the context of developing countries, since it is precisely in such countries that the aforementioned paradoxes, tensions and incompatibilities are most likely to impact governance outcomes.

In view of these critiques, Stubbs urges skepticism towards the claims of MLG. His central argument is for specificity. Following Dolowitz and Marsh (2000) he encourages governance researchers to ask concrete questions such as "why do actors engage in policy transfer? Who are the key actors involved in the policy transfer process? What is transferred? From where are the lessons learned? What are the different degrees of transfer? What restricts or facilitates the policy transfer process?" and "How is the project of policy transfer related to policy success or policy failure? (Dolowitz and Marsh $2000,8)$. These questions are, of course, quite particular. However, Stubbs' call for analytical frames and methods capable of dealing with diverse empirical contexts and histories re-occurs in a range of discussions on the relations between governance and society. As we will see, various approaches, in spite of internal differences, advocate detailed ethnographic or micro-sociological approaches as indispensable methods if the aim is to understand the actual contexts and effects of governance.

As should be clear from this discussion, MLG raises as many questions as it resolves. These are questions of epistemology and method, and they are questions about how to engage seriously with the specific settings and contexts of environmental governance in developing countries. ${ }^{5}$ To understand such contexts, we need better social scientific tools to deal with issues such as the specific relations between state and non-state actors, relations between agency and power, and with questions of responsibility and equity. In the next section, I therefore turn to a discussion of democracy, accountability and civil society relations. 


\section{Democracy, Accountability and Civil Society}

As noted, the concept of multilevel governance was originally developed specifically to analyze multidimensional governance within the EU. Among other things, criticisms of MLG highlight the quite different political and social contexts of governance in developing countries. These differences have to do with issues that include forms of government (which may not be democratic), the level of poverty and amount of resources available for governing, and the sophistication of infrastructure, administrative systems and, thus, capacities for governance. These are all pertinent issues to consider in the context of REDD+ governance.

\section{Additionally, criticisms pointed to the formalist} epistemology of MLG theory. One important consequence is that MLG, whether in hierarchical and polycentric form, engages with issues of power, culture and history in very particular ways. ${ }^{6}$ Thus, there are inherent limitations to what one might hope to achieve by adopting an MLG approach to address the challenges faced by REDD+ governance initiatives. For example, it is hard to see what concrete inputs MLG theory might give to the complex questions of benefit distribution and land use, which the CIFOR project aims to address. In this section, therefore, I turn to a different body of research, which has offered a number of illuminating analyses of state-society relations, of democracy, and of accountability.

According to both the comparative political economist Peter Evans and the anthropologist Jonathan Fox, specific relationships between state and society play an important role in shaping the outcomes of development activities.
Evans (1996) argued that "synergic" relations between state and society are conducive to the attainment of developmental goals. Synergy, for Evans, comprises two elements: complementarity and embeddedness. Complementarity refers to "mutually supportive relations between public and private actors", in which both governments and civil society contribute to the attainment of developmental goals, while maintaining a clear division of labor. Embeddedness is used to describe the establishment of closer relations between public officials and citizens. Using these concepts, Evans analyzed the success of Mexican irrigation systems as premised on the effective collaboration between the state, which provided infrastructure and technologies, and citizens, who provided labor to operate and maintain these systems. Thus, state and citizens were "complementary". However, this complementarity could arise only because of officials' active and direct engagement with citizens; that is, their embeddedness in civil society. For Evans, embeddedness is thus a key factor that promotes effective and efficient interactions between systems of governance and local communities.

Whereas Evans' analyses centered on "synergy", Jonathan Fox (1996) analyzes the co-production between state and society relations, defined as "co-ordinated joint efforts" between actors within both domains (1996, 1094). In spite of some differences, these authors seem to agree that two aspects are crucial for the study of such relations. First, both argue that there is a need for in-depth analyses of the nature and specific qualities of the state apparatus within the territory of which any governance 
initiative takes place. For instance, Evans' argues that a robust state that is able to ensure efficient delivery of public goods and services is crucial in order to foster collaboration with civil society and thus facilitate the "embeddedness" required to reach developmental goals. Likewise, the state is central because of its ability to offer incentives with which to get civil society to engage proactively in governance initiatives. Thus states may introduce laws and regulations that create opportunities for civil society to organize and provide inputs from below, for instance through decentralization or recentralization, or they may make laws that hinder the active participation of civil society actors. While Fox agrees on the importance of the state, he argues that laws and regulations ("structures") are not the only determinants in inducing local collective action. Drawing on an actor-oriented approach, he insists that civil society organizations and actors possess their own agency, and thus the capability to organize even in spite of unfavorable laws and regulations. Further he notes, in line with the polycentric view of MLG, that the state is not monolithic. He argues that political conflicts unfolding within the state itself generates spaces of opportunity, where civil society can operate, intervene, or help tip the balance towards one approach or decision rather than another.

What Fox helps us see, therefore, is that a "synergetic" and non-conflictive relationship between state and society (or even relations within the organization of state governance) is not necessarily required to stimulate local collective action. Nevertheless, like Evans, he emphasizes the importance of identifying areas in which states can create "opportunities" for such action. He also points to the need for careful empirical investigations of the particular ways in which different parts of civil society responds to such opportunities, and to their efforts to "scale up" their collective action by engaging with state level governance.

Secondly, both Evans and Fox highlight the importance of the notion of "social capital" for the analysis of statesociety relations. The version of social capital usually discussed in the context of development policy was originally introduced by Robert Putnam $(1993,167)$ to connote the "stock" of "norms of reciprocity and networks of civic engagement". Both Evans and Fox agree that existing social norms and degrees of trust contributes in important ways to the ability of civil society to take collective action, though, at least for Fox, they are not prerequisite for such action. Yet, both suggest that social capital can be nurtured and scaled up to create local level organizations that effectively deliver developmental services, and that development researchers should take a keen interest in analyzing how and why this happens.

In sum, these studies suggest that the study of "synergetic" relations between state and society entails the need to analytically unpack the notion of governance. In this respect, they align with MLG theory. They oblige us to carefully attend to the various forms of interactions, including collaboration and repression that are at play in any complex situation of governance. In particular, they urge attentiveness to the multiple forms of agency that are at play in governance, and to the cultural and social norms that inform the actions taken by different governmental and civil society bodies.

This body of literature therefore makes a significant contribution to the understanding of state-society relations, especially collaborative interactions carried out in politically and socially complex settings. Even so, it also has tensions of its own. First, as implied by Fox's discussion of political disagreements even within states, Evans' normative notion of synergy is misleading to the extent that it presumes that only harmonious, non-conflictive relations between state and society can lead to the achievement of development goals. In particular, centering analysis on synergetic relations risks downplaying, or evaluating as inherently negative, interactions premised on political difference. Thus, it does not offer any tools for understanding the processes of contestation and negotiation over policy goals that are invariably part of complex governance situations. ${ }^{8}$ Further, the very terminology of state-society relations, even as it is rendered fluid, has as its starting point a clear dichotomy between state and society. It presupposes that the state and society are both internally homogenous and mutually exclusive, thereby inhibiting analysis of the multiple emergent and hybrid relationships that belong to neither domain. In contrast 
to the presupposition of internal homogeneity, it is important to realize that states are not uniform but consist of cross-cutting networks, discourses and practices that may, and often do, conflict - for example in terms of their views on natural resource management. Likewise, civil society is by no means homogenous. Indeed, civil society organizations are often stratified along lines of wealth, class, ethnicity, gender, political affiliation, religion, and/ or cultural norms. Recognizing this diversity obliges us to search for modes of analysis attuned to the dynamic and power-saturated interactions between actors both within governments, within civil society and running across these distinctions. The success or failure of development goals is ultimately a consequence of such interactions, and the negotiations and decisions to which they give rise (once again, we can think of the contested issues of benefit sharing and land use for immediate examples).

To facilitate the unpacking of dynamic power relations between state and civil society, the literature on decentralization and devolution within natural resource management (NRM) offers a fruitful avenue. Analysts such as Jesse Ribot, Anne Larson, Ashwini Chhatre and John Ackerman are primarily interested in understanding how devolution alters existing power and accountability relations.

According to Jesse Ribot (2004), decentralization generally refers to a process that aims to transfer power from a central to lower level of governments in a politicaladministrate and territorial hierarchy. Examples of such lower level governments are regional, provincial or municipal level administrative or democratically elected government bodies. Devolution, on the other hand, connotes a wider scale of power transfer from central to lower level institutions that include not only local level government bodies but also private sector, NGOs, and community level organizations (Larson and Soto 2008). Examples of community level institutions include democratically elected local bodies, customary villages, and user committees (ibid.). Thus devolution is an important analytical tool for studies of the broader societal effects of power transfer. The notion of accountability is crucial in order to understand the consequences of these new forms of delegation of power. For Schedler (1999), accountability is composed of two elements: answerability "the obligation of public officials to inform about and to explain what they are doing and enforcement, which is "the capacity of accounting agencies to impose sanctions on power holders who have violated their public duties".

Devolution within NRM has been promoted on several grounds. Ribot (2004) argues that, compared with central level government, local level institutions have a comparative advantage in the design and implementation of policies and initiatives that fit local specificities, since they are more knowledgeable of local ecological conditions. Devolution is also argued to facilitate democratic forms of decision making and to promote equitable and fair distribution of benefits through societal participation in policy making. Further, societal participation in the management of resources is important, as it contributes to empowerment and livelihood improvement of involved people (Chambers et al. 1989; Ribot 2004). In practice, however, these potential benefits are not fully realized in many cases. Drawing on a review of a number of studies, Larson and Soto (2008) conclude that the actual outcomes of devolution are quite variable and contingent upon a number of factors. Among others, these factors include (1) which local level government bodies or community institutions are chosen for the delegation of power, (2) the extent to which these institutions are representative of and accountable to the local population and (3) what specific kinds of power (administrative, financial and political) they receive.

According to Ribot et al (2008), "institutional choice", by which the authors mean the choice of which levels or types of institutions that are to be empowered under devolution, has significant implications for local democracy and equity. For example, lower level governments and community institutions differ in terms of the degree to which they are representative of and accountable to local population. Some local (regional, local or municipal) governments and community level institutions may be upwardly rather than downwardly accountable. Likewise, community level institutions in such diverse shapes as customary villages, NGOs, and user committees may not be accountable to or representative of the local population as compared with democratically elected community level bodies. Under such 
circumstances, devolution may result in neither more democratic forms of decision making nor more equitable distribution of benefits. Instead, these circumstances create the risk of elite capture.

Elite capture designates the well-known phenomenon, in which privileged local actors or organizations either acquire benefits intended for poorer people in their communities, dominate local decision-making arenas (Ribot 1993), monopolize public benefits and resources (Platteau \& Abraham 2002), or misappropriate resources and public funds (Platteau \& Gaspart 2003; Ribot 2004). In fact, elite capture could be said to exemplify situations in which state and society have blurred in such a way that elite community members are also state representatives, or vice versa. In this situation, the dichotomy between state and society can offer little analytical help. Neither is much help offered by Putnam's normative concept of "social capital", which assume harmonious relations among local actors as the "natural state" of social affairs and depoliticizes the dynamic and conflictive nature of social interactions (Ackerman 2004).

The variable and contextual effects of institutional recognition have also been noted within NRM (e.g. Larson and Soto 2008). Since lower level governments and community level institutions have interests in and different incentives for the adoption of sustainable NRM, the mere transfer of power to such units of governance cannot be assumed to automatically lead to more sustainable NRM. For instance, a series of decentralization reforms in Indonesia resulted in the delegation of substantial powers to provincial and district level governments, who were neither accountable to central government nor to local populations but had a keen interest in generating revenue through granting concessions (Indrarto et al. 2012). As concessions granted to logging, mining and palm oil plantation proliferated, the problem of deforestation and forest degradation was exacerbated.

Ribot and Larson (2005) further note that attention to the specific kinds of power that are delegated to local levels of governance is important, since different forms of power may enable or disable institutions from effectively governing natural resources. For example, if central government transfers only administrative power (e.g. duties and responsibilities) to lower level institutions without backing it with sufficient financial and political power, this is likely to create administrative burdens rather than increasing governance capability. This seems to be the case in many developing countries where central governments tend to retain power and control over resources even under decentralization reforms (see. Ribot et al. 2006). As the Indonesian case indicated, the delegation of power to lower level units without the simultaneous introduction of "checks and balances" can also lead to serious problems with resource degradation.

These studies of accountability within governance institutions contribute significantly to our understanding of the effects of devolution on local democracy and sustainable environmental outcomes. Even so, they have also been criticized on various grounds. The first point of contention is that much of the literature on devolution conceptualizes power as a "substance", held, in different quantity, at different levels of governance. This concept of power risks disabling analytical recognition of the power and agency of actors at the lower levels. The following section looks more closely at studies inspired by the Foucaultian (e.g. 1990, see also Latour 1986) notion that both power and resistance exists everywhere and must be traced in its minute manifestations.

Similarly, studies by Ackerman (2004) and Chhatre (2008) have highlighted the need for more careful analysis of the particular ways in which local populations manage to exercise power through efforts to make government officials accountable to them. In particular, Chhatre (2008) used the notion of "political articulation" to identify a crucial dimension of how civil society actors come to influence policy or to achieve higher degrees of democracy and good governance. According to Chhatre, political articulation, defined as "the degree to which citizens and citizen groups can influence policy through democratic institutions" $(2008,13)$, can be attained by 1$)$ having regular free and fair elections to hold elected officials and leaders accountable, 2) societal monitoring of public affairs through expenditure audits and legislative reviews, 3) direct participation in policy dialogues and meetings and 4) supporting local media in informing and mobilizing civil society actors. 
In a related vein, Saito-Jensen et al (2010) and Lund and Saito-Jensen (2013) argued that the literature on devolution tends to focus on rather static social outcomes of elite capture, in which non-representative or unaccountable elites reap collective benefits from devolution. However, they also suggested that, though the early phases of devolution are highly prone to elite capture, such capture may be reversible over time. Inspired by Scott $(1985,1990)$ this work traced the ways in which even putatively powerless people also have the ability to counteract powerful bodies of official governance. Thus, they showed that, over time, devolution may enable disadvantaged groups to claim resources and power. Among the conditions for this to occur, these authors, like Chhatre, pointed to the importance of regular democratic election processes creating opportunities for local populations to make elected leaders accountable. Further, they argued for the establishment of formal rules and regulations that mandate different social groups to be represented in decision making processes, and which aim to ensure fair benefit sharing, and the need to create alignment between disadvantaged groups and other actors in order to leverage their agency. These studies, too, pointed to the importance of empirical in-depth analyses of struggles and contestations over power in the context of NRM.

Finally, it is noteworthy that the devolution literature has been criticized by proponents of a polycentric analytical approach (Andersson and Ostrom 2008). This critique centers in particular on the tendency of the decentralization and accountability literature to focus on subnational local level alone and its corresponding lack of attention to policy-making at other levels. Thus, Andersson and Ostrom argued that the study of devolution needs to simultaneously consider the roles of central government, NGOs, private associations, global actors, all of which play significant roles in shaping the interests and power of local level institutions in managing natural resources. Based on case studies of municipalities in Guatemala, Bolivia and Peru, Andersson and Ostrom's study aimed to test whether there was a systematic effect of decentraliztaion reforms on local units of government and the extent to which relationships between local units - rather than the properties of local governmnts - help explain local governmnt interest in forestry. To operationalize this research question they defined two dependent variables for effects on NRM: (1) the percentage of the municipal government personal that works with issue related to NRM and (2) whether the mayor viewed natural resource governance as a political priority for the municipal administration. As independent variables, they used the degree of decentralization (defined in terms of rights and authorities of municipalities in NRM), the amount of financial transfers from central to municipalities, population density, the mayor's education, and the amount of municipal meetings held with NGO and CBOs about NRM. Based on the correlation analysis, Andersson and Ostrom found that decentralization does not have significant or uniform influence on the degree of interests of local government in NRM. In contrast, institutional incentives from various levels such as the frequency of municipal meetings with NGOs and CBOs about NRM, and the financial transfers from the central to local governments were shown to be significant.

In spite of its sophisticated quantitative analysis, however, the epistemological and methodological problems identified by Stubbs (2005) are still present in this study. For example, the specific selection of variables and their interrelationships are by no means obvious and could be problematized from the point of view of more detailed ethnographic study of these contexts. As well, the generality of the conclusions that Andersson and Ostrom draw means that it is quite unclear how the specificities of governance interactions, including their outcomes in terms of accountability and delegation of power can be analyzed from within this framework. For a different set of analytical tools to deal with such issues, I turn now to a discussion of studies of development and the environment inspired by Michel Foucault's notion of governmentality. 


\section{Governmentality and Environmentality ${ }^{9}$}

In this section, I focus on a body of literature that has centered on the analysis on the politics of development and government. ${ }^{10}$ Because there is a vast body of literature on this topic, the material presented here is necessarily very selective. Hence, I focus in particular on four figures, namely, James Scott, James Ferguson, Tania Li and Arun Agrawal. The title of this section, governmentality and environmentality, speaks to the influence of the thinking of Michel Foucault (2008) on most of the work covered here. Governmentality was Foucault's analytical term for the emergence of new techniques and strategies for governing in the 20th Century, which centered not on coercion and subjection but rather on operating on subjects in such ways that they would internalize particular norms and modes of action. With the exception of James Scott, this idea has informed all the work covered in this present section. Arun Agrawal's notion of environmentality, in particular, is a direct application of governmentality in the context of environmental issues.

The political scientist James Scott has offered a number of important analyses of the relation between state action and peoples' way of resisting the state. Much of his early work, as well as his most recent book The Art of Not Being Governed (2009), has analyzed ways in which local actors, especially poor and under-privileged ones, attempt to evade state control and repression.

The notion of resistance was the crucial idea in his early work. Based on studies of Malay peasants, and peasant rebellions more broadly, Scott argued that market economies have often disrupted stable social structures premised on patron-client relations, which form the basis for the traditional "moral economy" of peasants (1977). Though patron-client relations are premised on unequal relations of power, Scott argued, such relations are also embedded in long-lasting patterns of social interaction and local people often prefer these established patterns to the uncertainties of the market. Nor is this difficult to understand, for in fact locals are often able to enter market competition only on very disadvantageous terms. This is why the entrance of market forces into local contexts is often met with resistance. Such resistance might take violent form. More often, however, resistance is insidious, consisting of multiple, miniscule ways of subverting, working against, or around, official institutions, development organizations or other powerful actors. Such forms of resistance are referred to by Scott as the Weapons of the Weak (1985). In Domination and the Arts of Resistance (1990), Scott discusses resistance in terms of a distinction between public and hidden transcripts. Public transcripts refer to normalized, routine forms of public interactions between "dominators" (such as public officials or company owners) and "the oppressed" (such as poor farmers). In contrast, hidden transcripts describe the ways in which oppressed people interpret and criticize the powerful when out of public view (cf. Goffman's (1959) discussion of front-stage and back-stage behavior). Hidden transcripts form the backdrop to any kind of formal and proper engagement and provide the impetus for concrete acts of resistance.

Complementing this interest, Scott's major work Seeing Like a State (1998) analyzes the particular rationality 
that undergirds states' ways of thinking, "seeing" and intervening in the world. In this work, Scott pursued his inquiry into the relations between government and resistance from the point of view of the rationalities of government. Scott argued that the major disasters of state initiated social engineering are due to a conjunction of four factors. The first factor is the "administrative ordering of nature and society" (Scott 1998, 4); that is, the state's efforts to make people and territories legible by classifying and standardizing them. The second factor is "high-modernist ideology", an uncritical optimism about the ability to rationalize and render efficient cities, villages and people. The third and fourth factors are the existence of a more or less authoritarian state and a "prostrate civil society" (Scott 1998, 5) unable to resist its plans.

Scott's arguments can be related to anthropologist James Ferguson's analyses of the depoliticizing effects of development interventions (1990). Ferguson's analysis is less sweeping than Scott's, as it relies neither on a universal dialectics between oppression and resistance, nor defines a general set of explanatory factors. Nevertheless, there are significant overlaps between their analytical projects. Ferguson's The AntiPolitics Machine offered a detailed ethnographic study of a development project in Lesotho. The starting point was Ferguson's perplexity upon noticing the peculiar manner in which Lesotho's history, culture and political economy was represented in official development reports, written in order to prepare the grounds for new initiatives. Specifically, Ferguson observed that central facts about history, culture and political economy were in fact either omitted or grossly misrepresented in these reports. Since, as he wrote, these analyses were written by top-quality development professionals from highly regarded institutions, the problem could not simply be presumed to be "error", or "the sign of gross ignorance or incompetent scholarship" (Ferguson 1990, 27). Rather, drawing on Foucault, he argued that development practitioners are part of formations of power and knowledge that differ in fundamental ways from those of academic scholars. Hence, Ferguson's key argument was that the systematic misrepresentation of Lesotho was necessary in order to turn the country into a lesserdeveloped country and thus prepare the ground for development interventions (see also Pigg 1997).
Similar to Scott, but in much more detail, Ferguson showed how development organizations turn countries like Lesotho into objects in need of improvement precisely through the techniques these organizations have at their disposal: "the technical, apolitical, 'development' intervention" (Ferguson 1990, 28). Ferguson emphasizes that developing countries, from the point of view of development organizations, are never seen as fundamentally shaped by their political and cultural histories. Analyses that point to political and historical factors as determining underdevelopment are never offered by such organizations, he surmises, because these forms of analysis literally disable the kinds of interventions that such organizations are able to provide in order to lift the countries out of poverty. This is the sense in which development policy, for Ferguson, is an anti-politics machine; an apparatus for removing politics from the set of concerns needed to take into account when trying to understand the problems a developing country faces.

Both Scott and Ferguson identify a particular form of governmentality, a way in which states, bureaucracies and development organizations think and operate that relies predominantly on technical procedure and routinely legitimizes its claims with reference to economic and technical rationality. Both also show that this form of governmentality has great difficulties handling real world complexity, local variation and cultural difference and has, in fact, often deliberately dismissed concerns with such issues as irrelevant for policy.

The anthropologist Tania Li has added to the governmentality literature by depicting development initiatives as instantiating a "will to improve" that disables development organizations from attending to local, cultural and historical complexity (Li 2007). In her The Will to Improve, Li intends "to make improvement strange, the better to explore its peculiarities and effects" (Li $2007,3)$. Thus, she proposes an analytical strategy that aims to understand the practices and assumptions that development organizations bring to their work, and the ways in which messy local realities are rendered in the form of "linear narratives of problems, interventions, and beneficial results" (Li 2007, 4, see also Mosse 2005, Mosse and Lewis 2005). This form of analysis is inspired both 
by Scott's critique of development's "high modernism" and Ferguson's analysis of development's depoliticizing effects. Li augments these approaches by insisting that while development initiatives describe themselves as non-political, they are often interpreted as "provocations" by some or many of the affected actors. Thus it is no surprise that development initiatives often give rise to various forms of resistance and contestation. The effects of any initiative must therefore be sought in the interplay between intended policy consequences and the ways in which diverse stakeholders and organizations respond to and translate them. In short, this mode of analysis consists of an analysis of the dialectical movement between "practices of government" and "practices of political challenge" to such government. In this sense, Li's approach is less "pessimistic"than Ferguson's, which posits the "logics" of development or and local action as mutually exclusive. Li's analytical approach allows her to trace a variety of "contradictory effects" of government, some of which may be "perverse" (Li 2007, 18), but others of which might be hopeful. Her ethnographically grounded research strategy thus centers on the simultaneous analysis of governmental interventions and on what happens when those interventions become entangled with the processes they aim to regulate and improve. Li's anthropological approach is also noteworthy for its eclectic combination of the analytics of Foucault and Gramscian Marxism. With Foucault, she insists that power is always "multiple" and cannot be "totalizing and seamless" (Li 200, 25). At the same time she follows a broadly Gramscian line of inquiry in insisting on seeing development initiatives in the context of "hegemonic" situations, overdetermined by specific, historically evolved, "constellations of power in particular times and places" (Li 2007, 27).

Arun Agrawal's Environmentality: Technologies of Government and the Making of Subjects (2005) offers a final important example of governmentality studies that deals specifically with environmental issues in India. While Agrawal, too, is inspired by Foucault, his analytical orientation is somewhat different from the approaches I have discussed so far. In particular, his work allows for a somewhat more "positive" view on development interventions. Centrally, Agrawal insists that governmentality has other and different consequences than repressing local actors, engendering contestation, or creating "perverse" responses. Inspired as much by Elinor Ostrom's approach to common property as by Michel Foucault's analysis of the microphysics of power, Agrawal is interested in the interplay between governmental aims to standardize and regulate society and nature and the responses of local actors to these efforts. In contrast to the previous authors, however, he is interested not only in accounting for the negative unforeseen consequences of development but also for the promise they hold.

Agrawal therefore mounts a sympathetic critique of development anthropologists and political scientists at once. For example, he lauds Ostrom's common property approach for its gradually increasing interest in "contextual variables", "decentralized mechanisms of environmental politics", and its "attention to the origins of commons institutions, and analyses of heterogeneities within groups" (Agrawal 2005, 208). Yet, even as CPR studies have begun to take history, context and politics more seriously, he adds, "the effects of politics on resources are always tracked through institutions" (Agrawal 2005, 208). Even if it is increasingly recognized that "variations in institutional arrangements to govern environmental goods can have a marked effect on their disposition and that successful forms include those under which users cooperate with each other to govern resources locally" (Agrawal 2005, 207), it remains the case that social practices continue to be seen as "the consequences of institutional transformations". In contrast "institutions are seldom the visible symptoms and markers of social practices" (Agrawal 2005, 207).

In other words, the analytical problem identified by Agrawal is two-fold. On the one hand, political science approaches to institutional analysis tend to assume a one-way causality where initiatives and policies transform social practice but not vice versa. This underplays the manifold ways, depicted by Scott and $\mathrm{Li}$, in which local actors may resist or even transform policy. On the other hand, development policies and initiatives are themselves seen as oddly un-social. This renders invisible the particularity of the cultural views that inform policy thinking, not least the technical orientation and the economistic and rational mindsets that guide most development programs. Yet, on the other 
hand, against scholars like Scott and Ferguson, notes that the unforeseen consequences of development can be positive as well as negative. As well, Agrawal insists, institutions of environmental governance have opportunities for becoming more reflexive and better at learning from both intended and unintended consequences.

Agrawal proposes that the relative success of community-based conservation in Kumaon, India, is premised on the "simultaneous implementation of three strategies". The first is the "creation of governmentalized localities that can undertake regulation in specified domains". The second is "the opening of territorial and administrative spaces in which new regulatory communities can function". Finally, the third is "the production of environmental subjects whose thoughts and actions bears some reference to the environment" (Agrawal 2005, 14). Agrawal refers to this production of environmental subjects through policy initiatives as environmentality. Thus, whereas Kumaon inhabitants, as most other of the world's people, did not always take an interest in the environment (at least as understood by Western scientists and policy-makers), one important side effect of community-based conservation efforts is that villagers increasingly do think in environmental terms, at least some of the time. They have, Agrawal argues, been re-shaped as environmental subjects. To understand this outcome, he urges political scientists interested in environmental matters to attend to the ways in which "knowledges, politics, institutions, and subjectivities" come to be "linked together", through processes that construct the environment as a "domain that requires regulation and protection" (Agrawal 2005, 226) - and this from the point of view of not only policy makers but also local people. This is a multi-causal rather than a monocausal process, since "the making of new institutions at the level of the village cannot be understood without attending to the ecological practices that underwrote them, negotiations over their character and precise make-up, and the distributive conflicts they generated" (Agrawal 2005, 227).

Some central points can be drawn from these analyses. To understand the processes that environmental policies and initiatives set in motion, one has to look considerably beyond the question of how to rationally organize institutions at multiple level of governance. What is required to understand governmentality in the context of environmental issues is at once 1) an analysis of the forms of (competing) expert knowledges that shape policies, 2) attentiveness to the relations of power that are established through these knowledge practices, and how such power is used in efforts to regulate social practice, 3 ) the specificities of institutional practices and the ways in which they interact with the historical and cultural particularities of local social and ecological practices, 4) how these interactions may create new kinds of environmental (or anti-environmental) subjects. These points can be amplified and given additional analytical ballast by turning, finally, to a set of discussions emerging out of science and technology studies, on the coproduction of government and society. 


\section{Co-producing Knowledge, Government and Society}

In the final section of the review, I survey an approach to governance and society that focuses on their mutual constitution or co-production. This approach has been defined in particular by political scientist and science and technology studies scholar Sheila Jasanoff based at Harvard University (Jasanoff 2004). In a certain sense, the co-production approach takes the literature review full circle. On the one hand, this approach, while it has learned from the governmentality and environmentality studies discussed above, offers a different and distinct perspective on the relations between government and society. On the other hand, its very name co-production, sometimes known as co-construction, is shared with perspectives that I described in earlier sections (Fox 1996). However, the meaning and implication of coproduction is significantly expanded in the usage of Jasanoff and her colleagues. Thus, in States of Knowledge, Jasanoff defines co-production as a "shorthand for the proposition that the way in which we know and represent the world (both nature and society) are inseparable from the ways in which we choose to live in it. Knowledge and its material embodiments are at once products of social work and constitutive of forms of social life; society cannot function without knowledge any more than knowledge can exist without appropriate social supports" (Jasanoff 2004, 2-3). In other words, the quality of knowledge itself depends on its social contexts and forms of production. In this section I examine the implications of the co-productionist approach for environmental governance.

Governance, writes Martello and Jasanoff, in the edited volume Earth Politics (Jasanoff and Martello 2004a) "has been defined most neutrally as 'rules and institutions for the authoritative organization of collective life' (Donahue 2002, 1)" (Martello and Jasanoff 2004, 2). Most often, however, the very definition of governance is normative. This is the case, for example when governance is defined in terms of mechanisms for achieving mutually satisfactory solutions (Schmitter 2001, 8, compare Stubbs 2005 critique of MLG discussed previously) or when openness, participation, accountability, effectiveness and coherence are seen as obvious virtues and values of governance. The normativity embedded in such definitions of governance are particularly important to bear in mind in current contexts of globalization and MLG; situations in which "intermediate governing structures" and "decision-making bodies that are neither domestic nor international" proliferate (Martello and Jasanoff 2004, 3). For these reconfigurations of governance also make clear that the above-mentioned values cannot be taken for granted. ${ }^{11}$ In other words, once multiple cultures and forms of governance, each with their own histories and their own assumptions, encounter each other, the values system of Western governance can no longer be taken for granted.

The recent history of environmental politics offers particularly clear examples on the challenges and possibilities for governance created by such reconfigured relations between society and government. This is a history that has demonstrated "increasing interaction between scientific and political authority", "the salient role of non-state actors in both knowledge making and politics", "the emergence of new political forms in response to novel conjunctions of actors, claims, ideas, and events that cut across national boundaries", as well, 
crucially, as "the reassertion of local knowledge claims and local identities against the simplifying and universalizing forces of global science, technology, and capital" (Martello and Jasanoff 2004, 4-5).

As this diagnosis suggests, Martello and Jasanoff largely agree with the analyses offered by scholars of governmentality. More than these analyses, however, Martello and Jasanoff concentrate on analyzing the implications of the existence of diverse forms of local and global knowledge for the making of environmental governmental regimes. Thus, they argue, "the construction of both the local and the global crucially depends on the production of knowledge and its interaction with power. How we understand and represent environmental problems is inescapably linked to the ways in which we choose to ameliorate or solve them" (Martello and Jasanoff 2004, 5). Martello and Jasanoff therefore make much of the fact that international environmental organizations and governing bodies have come to increasingly recognize "the need to mobilize indigenous knowledge and promote community participation so as to improve people's lives in the developing world" (Martello and Jasanoff 2004, 8). However, this recognition is far from making decision-making processes easier. Rather than putting responsibility for making the right environmental decisions in the hands of the experts (the "epistemic communities" described in Haas 1990), the recognition of different forms of knowledge creates increasingly complex framings of environmental problems (cf. Hajer 1990). Thus, they exemplify, "endangered species gave way to... biodiversity loss, encroaching deserts to land degradation, and the linear notion of global warming to the more turbulent concept of climate change" (Haas 1990, 9).

The important point is that this increasing complexity is not simply a consequence of improved scientific knowledge, but of the interplay between knowledges. Following the tradition of science and technology studies (e.g. Latour 1987, Biagioli 1999), they emphasize that the very "ideas of physical and biological causality can scarcely be separated from normative assumptions about the agents and behaviors responsible for environmental harm" (Haas 1990, 11). By way of illustration they refer to the argument made by Anil Agarwal and Sunita Narain (1991), that treating all greenhouse gas emission as identical is a political, not a purely scientific, decision, since it "penalizes 'subsistence' emissions just as severely as 'luxury' ones" (Agarwal and Narain 1991, 11). Hence, the "superficial egalitarianism of a scientific calculation...concealed a profoundly political intention not to distinguish among different types of resource consumption" (Agarwal and Narain 1991, 12).

Digging into the normative underpinnings of scientific claims lead Martello and Jasanoff to critique the idea that science speaks truth to power. In its place, they draw on Donna Haraway's (1991) concept of situated knowledges. Thus, they ask: "How do societies undergoing... massive transformation know things? Where do they turn for credible information, and what even counts as information in today's complex and noisy networks of communication? How do widely dispersed actors, with no common experiential base, acquire shared knowledge, and what happens when they disagree about the immensely varied facts that are relevant for their survival? (Martello and Jasanoff 2004, 16). "These questions", they continue," so critical to the success of global governance, have remained unasked and largely unanswered" (Martello and Jasanoff 2004, 16, my emphasis).

On the one hand, these authors see the arena of environmental governance as a first mover, since it has allowed "formal admission" of situated knowledges into "global environmental regimes" (Jasanoff and Martello 2004b, 335). On the other hand, since they are skeptical of any legitimation of politics "by appeal to an autonomous, free-standing" science (Jasanoff and Martello 2004b, 338), they also criticize environmental regimes for their continued reliance on the distinction between the facts of science (viewed as a "universal public good") and local knowledge, which is really just 'belief' (Jasanoff and Martello 2004b, 338). The "unavoidable conclusion", they state, is "that natural and social order are co-produced through intertwined intellectual and social processes" (Jasanoff and Martello 2004b, 338). The recognition that knowledge is invariably historical and cultural, they surmise, is more "truly reflective of complex environmental realities" than any abstract or formal (governmental) model for handling such realities (Jasanoff and Martello 2004b, 339). 
In the conclusion to Earthly Politics, Jasanoff and Martello draw out a number of "guideposts for governance". First, they propose, it must be recognized that "institutions of global governance do not merely implement policies that are 'naturally' global but serve as construction sites, or signaling stations, for sorting out the very meanings of the global and the local" (Jasanoff and Martello 2004b, 341). Environmental multilevel governance thus cannot be understood in terms of abstract and idealized forms. Instead it but must be engaged experimentally; they must be constantly tinkered with and renegotiated with input from multiple, divergent forms of actors and knowledges. Second, the very act framing of policy problems as local or global has crucial implications in terms of whose voices are heard and which actors get to exercise power in relation to specific topics. Third, policy forums are themselves "important sites of meaning-making, and hence should be viewed as localities of political significance in and of themselves" (Jasanoff and Martello 2004b, 342). Again, policy is not a "neutral" matter of implementing the best solution based on the best available evidence, but is rather an inherently political activity. These observations lead Jasanoff and Martello to offer a series of suggestions for the co-production of governance and society within environmental regimes.

One of their most important recommendations is that institutions of governance need to become more selfaware and reflexive with respect to their "active role" in framing what counts as relevant issues and for whom. Institutions, they write, fail "to see their own hand in the creation" of the categories that make policies matter and this "imaginative blockage has to be countered" (Jasanoff and Martello 2004b, 343 ${ }^{12}$ ). Aside from encouraging transparency and the adaptation of best practice guidelines for "subjecting their methods of technical analysis, advice-seeking, and review to regular criticism",
Jasanoff and Martello also argue that mechanisms are needed "to force institutions, at regular intervals, to reflect on the rationale for accepted problem framings and alternatives to them" (Jasanoff and Martello 2004b, 344). The same reflexive requirement extends to questions of expertise. Expertise is never neutral, but "valid only within particular 'situated' frameworks of presumptions and practices" (345). All expert claims should thus also regularly be subject to review, criticism and revision. Improved critical capacity in particular relates to the "emergence of new domains or cultures of expertise" enabling the expansion of analytical and practical horizons, and breaking down the ingrained "imaginative blockage" of large institutions.

One way in which such domains of expertise may be brought to life is through "the creation of forums where lay knowledges could be routinely" be brought into non-hierarchical conversation with scientific expertise, such that both (or all) forms of knowledge can be mutually and "routinely critiqued and assessed" (Jasanoff and Martello 2004b, 345). Eventually, therefore, the "democratization of global governance", premised on the recognition of the co-production of governance and society, "calls for more than formal invitations to dialogue", and more than finding the right general model of multilevel governance. The emergence of more democratic environmental governance institutions entails also that "adequate support for their interventions" be given to those "heterogeneous populations" whose input is requested (Jasanoff and Martello 2004b, 347). Thus environmental institutions, global as local, "should seek proactively to lower the barriers to participation"13 and "notions of capacity building should be broadened so as to include the expertise needed to represent one's cause more competently" in relevant forums (Jasanoff and Martello 2004b, 347). 


\section{Summary \\ Theories and Methods for Studying Environmental Governance}

I am now in a better position to offer input for the development of a "theoretically grounded framework for the study of multi level governance and REDD+ through the review of theory and methods of direct relevance to MLG especially with regard to benefit sharing mechanisms and land use decisions".

The discussion of multilevel governance (MLG) theory showed that this theory comprises both a hierarchical and a polycentric model. As the discussion has suggested, the polycentric model is better aligned with all the other approaches that were covered in this review than the hierarchical model. Polycentric MLG offers the crucial insight that static structures and hierarchies of governance are increasing blurring, in tandem with the increasing interactions between more and more diverse stakeholders, at global and local levels, in processes of environmental governance. Hence, the conceptualization of governance systems as "complex overlapping networks" is very valuable. Even so, it remains somewhat unclear how polycentric MLG can contribute to the specific aim of analyzing, not to mention strengthening, benefit sharing mechanisms and land use decisions under REDD+. This problem relates especially to its positivist, rather than interpretive, epistemological assumptions, and to its quantitative, rather than qualitative and contextual, methodology. ${ }^{14}$ In short, while polycentric MLG seems well suited to the analysis of large scale quantitative data sets, aiming to pinpoint trends and tendencies based on heuristically chosen variables, it appears considerably less ideal for the study of currently evolving and still experimental governance systems, like the ones of emerging in the context of REDD+, which are likely to comprise new modes of governing and to shape new governance relations among different actors and draw upon multiple, variable stakeholders in doing so.

Hence, in later sections, I turned to a variety of more contextual, culturally located, historically grounded, and politically sensitive approaches from social science. While there are important differences among these approaches, they all engage in efforts to deal contextually with governance systems, or state-society relations. ${ }^{15}$ They share a common interest in unpacking the complexity of such systems, and view such complexity as empirical and situated, rather than formal and abstract.

Although these studies deal with different topics, and there are important disagreements between them, the epistemological and methodological presuppositions of these studies overlap to a significant extent. Epistemologically, they are interpretive and constructivist, concerned with meaning-making and political processes that are embedded in, and take part in shaping, governance systems. Methodologically, they employ in-depth studies of the cultures of governance and the cultures of civil society, as well as of the historically changing political relations between and within each of these cultures. One central difference from MLG, therefore, is that none of the latter studies begin with the identification of key variables. Indeed, studies from the anthropology of development and studies of decentralization, accountability and NRM exhibit a shared unwillingness to define key variables as a starting 
point of their analyses. Rather, these approaches view the question of key variables as an outcome of their inquiries, which result from empirically grounded analysis of the actors, relations, elements, forms and interactions that make particular governance systems and generate specific outcomes. Here it can be noted that the limitation of the otherwise comprehensive and interesting "earth system governance" framework is precisely that it aims to combine these two different approaches (MLG and other relevant theories) without reflexive attention to their incompatible epistemological and methodological assumptions.

However, the deliberate unwillingness to begin inquiry with the identification of key variables does not prevent these studies from specifying a number of central issues, which ought to be borne in mind when engaging with questions such as benefit sharing and land use under REDD+. For instance, while Evans' concept of synergy as arising from the combination of complementarity and embeddedness cannot easily be turned into quantitative variables, it can be used to specify consequential empirical questions for the multilevel governance and REDD+ project. Thus, the notion of complementarity can be used to guide inquiries such as "who are the public and private actors involved?", "what kinds of formal and informal relations do they have among and between one another?"' "do the involved actors perceive these relations as mutually supportive (why or why not?" "what do they think might change in these relations for them to become mutually supportive"? ${ }^{16}$ Likewise, the notion of embeddedness offers the opportunity to ask specific questions such as "which state officials (if any) have become embedded with which parts of civil society?" "for which reasons and as a result of which institutional and political processes?" "who has benefited from such embeddedness?" "has anyone lost out due to it?". These are very fruitful lines of inquiry, not for formal quantitative testing, but for in-depth qualitative studies of currently evolving governance systems under REDD+. Obviously, these are only suggestive starting points for building theory. The point is that building theory requires sustained engagement with the complex empirical realities of REDD+ governance systems and the contexts into which they are introduced. For most of the studies I have surveyed, theory is an outcome of such engagement rather than the premise for it. ${ }^{17}$
In the remainder of this section, I summarize more briefly the central contributions from the other approaches covered in the review. The central point is that each of these contributions can and should be interpreted similarly to the way in which I have just presented Evans' conceptual contribution: not as fixed and well-defined starting points, but as entry points for engaging with the complex realities of REDD+ governance.

Thus, Fox's concept of co-production as "co-ordinated joint efforts", which co-exist with political contestation, both within and between states and civil societies, helps us to decisively move away from a harmonious conception of governance, since it enables us to see the divisions and disagreements that exist within both states and civil society. Augmenting this attentiveness to the political and structural difference, scholars like Ribot, Chhatre and Larson, enable the formulation of critical questions about the ways in which governance initiatives create different relations of accountability and unaccountability. Once again, empirical specificity is central. It is not sufficient to argue for, or even design, a formally accountable system for dealing with benefit sharing and land use decisions, if the system, in actual practice, is accountable only to the elites capable of capturing the decision-making process. While these studies all do argue for the need to create formally accountable and inclusive processes they simultaneously they argue for the importance of continuously tracing how such processes lead to struggles and contestations that play out in practice -- in "real-time".

With the exception of the work of Arun Agrawal, the literature on governmentality takes a more bleak perspective on governance in developing countries. These are studies that, in direct contrast to MLG, focus on the politics of governance systems. Rather than viewing governance as offering a democratic and rational means for achieving beneficial social ends, Scott describes governance as infused with a high-modern ideology, which runs roughshod over local cultural difference. Ferguson's perspective on development organizations as anti-politics machines point in the same direction. It is indeed difficult to directly use these analyses to improve environmental governance. Yet, they are of crucial importance in helping us pose reflexive questions. Scott, Ferguson, Li and Agrawal all demonstrate that 
environmental governance is not an issue of finding optimal technical solutions for agreed upon problems, since the very agenda-setting and definition of what counts as important problems is the outcome of inherently political and contested processes. These studies also indicate that that no matter how carefully a governance system is designed, empirical governance processes are always prone to lead to unforeseen and, indeed, unforeseeable outcomes. Such outcomes are simply not avoidable by better design or more rational planning. They are rather inevitable effect of very complex empirical processes and relations.

While this perspective can offer no "theoretical guarantee" for the design of better governance systems, it has the benefit of encouraging a stance of sustained reflexivity. For example, it might lead to ask questions such as "whose problem" is benefit sharing, land use or carbon emissions levels? How have these problems been framed? Why in this way? Further, do local organizations, $\mathrm{NGOs}$, or other civil society bodies agree with the framing of these issues as most crucial for the success of REDD+? Why or why not? Do they even agree upon the agenda of REDD+ as such? Again, why or why not? Posing such questions is crucial in order to recognize the situatedness and specificity of the REDD+ interventions. It is equally incumbent to continuously attend to problems arising from the fact that different actors may have very different ideas about the central problems of REDD+. Given that different interpretations will shape the particular responses of involved actors to these governance initiatives, it is crucial to understand why and from whence they arrive.

In his analysis of environmentality, Agrawal focused on the relation between different forms of knowledge and the question of how local knowledge can be included in decision making processes. Precisely this question holds pride of place in Jasanoff and Martello's co-production perspective. Rather than criticizing environmental governance for its limitations and failures to include local perspectives, Jasanoff and Martello praise contemporary environmental governance initiatives for their attempts to take seriously very diverse forms of knowledge. Indeed, they view the inclusion of multiple forms of situated knowledges as extremely important not just in terms of equity and accountability, but also in terms of the very quality of the knowledge on which environmental governance is based. In this view, the recognition that multiple forms of knowledge and different, even compatible, perspectives interact in any environmental governance system, helps facilitate more realistically complex and therefore more adequate framing of governance problems and solutions.

This argument may sound counter-intuitive, since governance is often interested in finding solutions, and rendering problems more manageable - rather than more complex. But Jasanoff and Martello's co-production argument suggests that a governance solution can never be any better than the way in which it is framed. Simple solutions may look excellent on paper but invariably give rise to subsequent complications, not part of their original framing. Indeed, development governance is full of initiatives framed by input from the best development experts, which ran aground, generated political opposition, or had multiple unforeseen consequences - or consequences foreseen only by people that were not heard - because the initial framing of the problem was not sufficiently complex. Hence, Jasanoff and Martello argue for attempts to overcome the "imaginative blockage" that still inhibits governance institutions from taking alternative, incongruent, or really foreign, perspectives seriously into account. If Jasanoff and Martello had their way, governance institutions would be forced to reflect on the rationale for the problem framings, on possible alternatives, and on the way in which any problem framing privileges certain forms of expertise while excluding other kinds.

Force, of course, is only required, insofar as institutions are incapable of recognizing the benefit such reflexive questioning might bring. Insofar as the aim of the multilevel governance and REDD+ project is to identify options for the design of new REDD+ governance institutions, we can see it as directly related to what Jasanoff and Martello describes as the "emergence of new domains or cultures of expertise" within governance. Attending closely to the knowledge-making processes whereby these new forms of governance come to be designed and to the political processes that determine who will be part of them must therefore be a central goal 
for the project. Hence, it appears crucial for this project to continuously reflect upon questions including:"whose knowledge and claims to forest resources and rights are recognized and legitimized under REDD+", "how do existing and emerging power relations among actors residing in different and overlapping political domains shape such processes and outcomes", and "what are the different options through which we may promote accountability and inclusiveness in these specific contexts?"
In that sense, I might view the multilevel governance and REDD+ project as having the purpose of overcoming the imaginative blockage depicted by Jasanoff and Martello. It can begin doing so by paying attention to the complex processes whereby governance and society become co-produced. As I have suggested, the rich literature I have surveyed in this review provides multiple avenues of inquiry that can help in this endeavor. 


\section{Bibliography}

Primary literature refers to the literature cited in this review. Second literature refers to the additional additional relevant texts that are not specifically discussed in this reveiw.

\section{Multilevel Governance Theory}

\section{Primary references}

Bache I and Flinders M, eds. 2004. Multi-level Governance. Oxford, Oxford University Press.

Betsill MM and Bulkeley H. 2006. Cities and the multilevel governance of climate change. Global Governance 12: 141-159.

Bierman F, Betsill MM, Gupta J, Kanie N, Lebel L, Liverman D, Schroeder H, Siebenhüner B and Zondervan R. 2010. Earth system governance: A research framework, International Environmental Agreements 10: 277-298.

Bulkeley H, Davies A, Evans B, Gibbs D, Kern K and Theobald K. 2003. Environmental governance and transnational municipal networks in Europe, Journal of Environmental Policy and Planning 5: 235-254.

Clarke J. 2004. Changing Welfare, Changing States: New Directions in Social Policy. London, Sage.

Dolowitz D and Marsh D. 2000 Learning from abroad: The role of policy transfer in contemporary policy-making, Governance 13(1): 5-24.

Fairbrass J and Jordan A. 2001 Making European Union biodiversity policy: National barriers and European opportunities, Journal of European Public Policy 8(4): 499-518.
Hay C. 2004. Common trajectories, variable paces, divergent outcomes? Models of European capitalism under conditions of complex interdependence. Review of International Political Economy 11(2): 231-262.

Hooghe L and Marks GG. 2001. Types of multi-level governance, European Integration Online Papers 5(11). Available at http://eiop.or.at/eiop/texte/2001-011.htm.

Marks G. 1993. Structural policy and multi-level governance in the EC. In Cafruny A and Rosenthal G, eds. The state of the European Community 2: The Maastricht debates and beyond, 391-410. Boulder, CO: Lynne Rienner.

Ostrom E. 2010. Polycentric systems for coping with collective action and global environmental change, Global Environmental Change 20: 550-557.

Rosenau J 1997. Along the Domestic-Foreign Frontier: Exploring Governance in a Turbulent World. Cambridge: Cambridge University Press.

Stubbs P. 2005. Stretching concepts too far? Multi-level governance, policy transfer and the politics of scale in South East Europe, Southeast European Politics VI(2): 66-87.

\section{Secondary references}

Andersson K and Ostrom E. 2008. Analyzing decentralized resource regimes from a polycentric perspective, Policy Sciences 41: 71-93.

Sloat A. 2002. An actor-centered approach to multi-level governance: Expectations of Scotland's role in Europe, Regional \& Federal Studies 12(3): 156-180 


\section{Democracy, Accountability and Civil Society}

\section{Primary references}

Ackerman J 2004. Co-governance for accountability: Beyond 'exit' and 'voice', World Development 32(3): 447-463.

Andersson K and Ostrom E. 2008 Analyzing decentralized resource regimes from a polycentric perspective, Policy Sciences 41: 71-93.

Bebbington A, Guggenheim S, Olson E and Woolcock M. 2004. Exploring social capital debates at the World Bank. Journal of Development Studies 40(5): 33-64.

Bourdieu P. 1986 The forms of capital. In Richardson JG, ed. Handbook of Theory and Research for the Sociology of Education, 241-58. New York: Greenwood Press.

Chambers R, Shah T, and Saxena NC. 1989. To the Hands of the Poor: Water and Trees. New Delhi and Oxford: IBH Publishing.

Chhatre A. 2008. Political articulation and accountability in decentralization: Theory and evidence from India, Conservation and Society 6(1): 12-23.

Dasgupta P and Serageldin I. 1999. Social Capital: A Multifaceted Perspective. Washington D.C, The World Bank.

Evans P. 1996. Government action, social capital and development: Reviewing the evidence on synergy, World Development 24(6):1119-1132.

Fine B. 2001. Social Capital versus Social Theory: Political Economy and Social Science at the Turn of the Millennium. London and New York, Routledge.

Foucault M. 1990. The History of Sexuality: An Introduction (vol. 1). New York, Random House.

Fox J. 1996. How does civil society thicken? The political construction of social capital in rural Mexico, World Development 24(6): 1089-1103.

Larson AM and Soto F. 2008. Decentralization of natural resource governance regimes, Annual Review of Environment and Resources 33:213-39.

Latour B. 1986. The powers of association. In Law J, ed. Power, Action and Belief, 264-280. London, Routledge \& Kegan Paul.

Lund, JF and Saito-Jensen M. 2013. Revisiting the issue of elite capture of participatory initiatives. World Development. Available online first at http:// www.sciencedirect.com/science/article/pii/ S0305750X1300034X.

Platteau J-P and Abraham A. 2002. Participatory development in the presence of endogenous community imperfections, Journal of Development Studies 39(2): 104-136.

Platteau J-P and Gaspart F. 2003. The risk of resource misappropriation in community-driven development. World Development 31(10): 1687-1703.

Putnam RD. 1993. Making Democracy Work: Civic Traditions in Italy. Princeton, NJ, Princeton University Press.

Ribot JC. 1993. Market-state relations and environmental policy: Limits of state capacity in Senegal. In Lipschutz RD and Conca K, eds. The State and Social Power in Global Environmental Politics. New York: Columbia University Press.

Ribot JC. 2004. Waiting for Democracy: The Politics of Choice in Natural Resource Decentralization. Washington, DC, World Resources Institute.

Ribot JC, Agrawal A and Larson AM. 2006. Recentralizing while decentralizing: How national governments reappropriate forest resources, World Development, 34(11): 1864-1886.

Ribot JC, Chhatre A and Lankina TV. 2008. Institutional choice and recognition in the formation and consolidation of local democracy: Representation, Equity and Environment. Working Paper no. 35, World Resources Institute.

Ribot JC and Larson AM, eds. 2005. Democratic Decentralization Through a Natural Resource Lens. London: Routledge.

Saito-Jensen M, Nathan I and Treue T. 2010. Beyond elite capture? Community- based natural resource management in Mahmad Nagar village, Andhra Pradesh, India. Environmental Conservation 37(3): 327-335.

Schedler A. 1999. Conceptualizing accountability. In Schedler A, Diamond L and Plattner MF, eds. The Self-Restraining State: Power and Accountability in New Democracies, 13-28. Boulder \& London: Lynne Rienner.

Woolcock M and Narayan D. 2000. Social capital: Implications for development theory, research and policy. The World Bank Research Observer 15(2): 225-249. 


\section{Secondary references}

Berkhout F, Leach M and Scoones I, eds. 2003. Negotiating Environmental Change: New Perspectives from Social Science. Cheltenham, UK and Northampton, MA, Edward Elgar.

Fairhead J and Leach M 1996. Misreading the African Landscape - Society and Ecology in a Forest-Savanna Mosaic. Cambridge, Cambridge University Press.

Indrarto GB, Murharjanti P, Khatarina J, Pulungan I, Ivalerina F, Rahman J, Prana MN, Resosudarmo IAP, Muharrom E. 2012. The context of REDD+ in Indonesia: Drivers, agents, and institutions. Bogor, Indonesia: CIFOR.

Leach M, Scoones I and Wynne B, eds. 2005. Science and Citizens: Globalization and the Challenge of Engagement. London and New York, Zed Books.

Peluso N. 1991. Rich Forests, Poor People: Resource Control and Resistance in Java. Berkeley, University of California Press.

Ribot JC. 2007. Representation, citizenship and the public domain in democratic decentralization. Development 50: $43-49$.

Watts M and Peluso N 2001 Violent Environments. Ithaca, Cornell University Press.

Zerner C. 2000. People, Plants and Justice: The Politics of Nature Conservation. New York, Columbia University Press.

\section{Governmentality and Environmentality}

\section{Primary references}

Agrawal A. 2005. Environmentality: Technologies of Government and the Making of Subjects. Durham, Duke University Press.

Ferguson J. 1990. The Anti-Politics Machine: "Development", Depoliticization, and Bureaucratic Power in Lesotho. Cambridge, Cambridge University Press.

Foucault M 2008. The Birth of Biopolitics: Lectures at the Collége de France 1978-1979. New York, Palgrave MacMillan.

Goffman E. 1959. The Presentation of Self in Everyday Life. Garden City, New York, Doubleday Anchor Books.
Li, TM. 2007. The Will to Improve: Governmentality, Development, and the Practice of Politics. Durham, NC, Duke University Press.

Mosse D. 2005. Cultivating Development: An Ethnography of Aid Policy and Practice. London and Ann Arbor, MI, Pluto Press.

Mosse D. and Lewis D, eds. 2005. The Aid Effect: Giving and Governing in International Development. London and Ann Arbor, MI, Pluto Press.

Pigg SL. 1997. Found in most traditional societies: Traditional medical practitioners between culture and development. In Cooper F and Packard RM, eds. International development and the social sciences: essays on the history and politics of knowledge, 64-93. Berkeley, University of California Press.

Scott JC. 1977. The Moral Economy of the Peasant: Rebellion and Subsistence in Southeast Asia. New Haven and London, Yale University Press.

Scott JC. 1985. Weapons of the Weak: Everyday Forms of Peasant Resistance. New Haven and London, Yale University Press.

Scott JC. 1990. Domination and the Arts of Resistance: Hidden Transcripts. New Haven and London, Yale University Press.

Scott JC. 1998. Seeing Like a State: How Certain Schemes to Improve the Human Condition Have Failed. New Haven and London, Yale University Press.

Scott JC. 2009. The Art of Not Being Governed: An Anarchist History of Upland Southeast Asia. New Haven, CN and London, Yale University Press.

\section{Secondary references}

Agrawal A. 2003. Sustainable governance of commonpool resources: Context, methods and politics. Annual Review of Anthropology 32: 243-62.

Brosius PJ., Tsing A and Zerner C, eds. 2005.

Communities and Conservation: Histories and Politics of Community-Based Natural Resource Management. Walnut Creek, CA, Altamira Press.

Dean M. 1999. Governmentality: Power and Rule in Modern Society. London: Sage.

Foucault M. 1990. The History of Sexuality: An Introduction (vol. 1). New York, Random House.

Greenough PR and Tsing A 2003 Nature in the Global South: Environmental Projects in South and Southeast Asia. Durham, NC \& London, Duke University Press. 
Larner W and Walters W, eds. 2004. Global

Governmentality: Governing International Spaces. New

York and London, Routledge.

Lewis D and Mosse D, eds. 2006. Development Brokers and Translators: The Ethnography of Aid and Agencies. Bloomfield, Ct, Kumarian Press.

Li TM. 1999. Transforming the Indonesian Uplands: Marginality, Power and Production. Amsterdam, Harwood Academic Publishers.

Mosse D. 2004. Is good policy unimplementable: Reflections on the ethnography of aid policy and practice, Development and Change 35(4): 639-671.

Rose N. 1999. Powers of Freedom: Reframing Political Thought. Cambridge Cambridge University Press.

Rose N and Miller P. 1992. Political power beyond the state: problematics of government. British Journal of Sociology 43(2): 173-205.

Tsing A. 2005. Friction: An Ethnography of Global Connection. Princeton, NJ, Princeton University Press.

Yarrow T and Venkatesan S, eds. 2012. Differentiating Development: Beyond an Anthropology of Critique. Oxford: Berghahn.

\section{Co-Producing Government and Society}

\section{Primary references}

Agarwal A and Narain S. 1991. Global Warming in an Unequal World. Centre for Science and Environment, New Delhi.

Biagioli M, ed. 1999. The Science Studies Reader. New York \& London, Routledge.

Donahue J. 2002. Market-based governance and the architecture of accountability. In Donahue J. and Nye J, eds. Market-Based Governance. Brookings Institute.

Haas PM. 1990. Saving the Mediterranean: The Politics of International Environmental Cooperation. New York, Columbia University Press.

Hajer MA 1995. The Politics of Environmental Discourse: Ecological Modernization and the Policy Process. Oxford, Clarendon Press.

Haraway D 1991 Simians, Cyborgs, and Women — The Reinvention of Nature. New York, Routledge.
Jasanoff S 2004. States of Knowledge: The Co-Production of Science and Social Order. New York, Routledge. Jasanoff S and Martello ML, eds. 2004a. Earthly Politics: Local and Global in Environmental Governance. Cambridge, MIT Press.

Jasanoff S and Martello ML. 2004b. Conclusion: Knowledge and governance. In Jasanoff S and Martello ML, eds. Earthly Politics: Local and Global in Environmental Governance, 335-351. Cambridge, MIT Press.

Latour B. 1987. Science in Action: How to Follow Scientists and Engineers Through Society. Cambridge, MA, Harvard University Press.

Martello, ML and Jasanoff S. 2004. Introduction. Globalization and environmental governance. In Jasanoff S and Martello ML, eds. Earthly Politics: Local and Global in Environmental Governance, 1-31. Cambridge, MIT Press.

Schmitter P. 2001. What is there to legitimize in the European Union... and how might this be accomplished? Political Science series no. 75. Institute for Advanced Studies, Vienna.

\section{Secondary references}

Latour B. 1986. The powers of association. In Law J, ed. Power, Action and Belief, 264-280. London, Routledge and Kegan Paul.

Latour B. 2004. Politics of Nature: How to Bring the Sciences into Democracy. Cambridge, MA \& London, Harvard University Press.

Jasanoff S and Wynne B. 1998. Science and Decisionmaking. In Rayner S and Malone EL, eds. Human Choice and Climate Change, 1-87. Battelle Press.

Pickering A and Guzik K, eds. 2008. The Mangle in Practice: Science, Society and Becoming. Durham, NC, Duke University Press.

Rottenburg R. 2009. Far-Fetched Facts: A Parable of Development Aid. Cambridge, Ma and London, MIT Press.

Verran H. 1998. Re-imagining land ownership in Australia, Postcolonial Studies 1(2): 237-254.

Verran H. 2002. A postcolonial moment in science studies: Alternative firing regimes of environmental scientists and aboriginal landowners, Social Studies of Science 32(5/6): 729-762. 


\section{Endnotes}

1 The notion of theoretical grounding is itself part of the discussion covered in this review, since it discusses approaches that have quite different notions of theory, methods and their relation, not least whether theory is used formally generate hypotheses to be confirmed or falsified, or whether theoretical concepts are heuristic tools that guide the interpretation of empirical material. The notion of "grounded theory" from sociologists Glaser and Strauss offers a strong version of the latter, in which theory is assumed to emerge exclusively from coded ethnographic data.

2 One project member queried the usage of Foucault rather than e.g. approaches from political ecology especially on the issue of power. The political ecology literature is of course massive, and it is influenced by diverse conceptions of power including Marxist and Foucaldian notions, as well as various combinations. I would certain encourage project members to look at this literature in more detail. The selection of material in this review is based on my own estimation that Foucault's approach to power remains more flexible and precise than most alternatives even today. Of course it is also noteworthy that each of the highly regarded scholars I discuss in the section of governmentality has been inspired by precisely Foucault. Another interesting option in terms of conceptualizing power is to turn to actor-network theory and the work of Bruno Latour, to which Jasanoff's idea of co-construction (presented in the last section) is much indebted. See for example Latour's 1986 article "The powers of association".

3 Corbera and Scroeder (2010) follow Biermann et al's framework in their discussion of "Governing and implementing REDD+". The discussion is interesting but their operationalization of the earth systems framework suffers from some of the same problems as the framework itself. On the one hand, the framework is appealing because it is so comprehensive, promising to be able to take into account everything, from local to global level governance, power and accountability, biophysical features and cultural events. On the other hand, the analysis of these different aspects are informed by vastly different traditions of social thought, which pull in different directions. Thus, in both Bierman et al and Corbera and Schroeder, there are unanalyzed tensions between such issues as structure and agency (sometimes structure seems to be determining, sometimes people have the ability to change structures), norms/values and practices (sometimes norms and values seem to determine practical action, sometimes practices give rise to norms and values), selforganization or external control (sometimes governing bodies are said to be self-organizing but sometimes they are "steerable" by rational design), as well as changing conceptions of power (sometimes invoked in a Foucaudian sense, sometimes in the sense of liberal political theory), knowledge (sometimes privileging science, sometimes arguing that indigenous knowledges are equally important), etc etc. Indeed, the very question of what earth systems governance is changes, since it is sometimes presented as a realist argument and sometimes as a constructivist framework, sometimes as a depiction of reality, sometimes as a normative argument. A whole paper could be written about this, but I hope this gives a flavour of the issues at stake.

4 The logic behind the selection is that the starting point is MLG, which is taken as obviously relevant for the project. To get a reflexive view of the strengths and limitations of MLG it thus seems important to introduce some critical and/or different positions. However, due to disciplinary, epistemological and methodological differences, there are not many interpretive social scientists that discuss MLG in much detail. That's why Stubbs gets this prominent position. Concerning Foucault's admiration, I think it has never been very strong by "scientists", but it is clearly undiminished in largest parts of social and cultural theory, including political ecology, environmental studies, cultural geography and science and technology studies. Part of it is probably to do with rather basic (though not necessarily unsurmountable) differences as regards the view of what (social) science is, what kind of knowledge it produces, how it produces it, why it produces it, and so forth. See also the note on "theoretical grounding" above. 
5 Stubbs'study is itself a discussion of the epistemological and conceptual limitations of MLG, so in that sense I am presenting its results. I hold it to be valuable for the reason given in endnote Il above, that precisely MLG is the starting point for much of the research going on in the project. Hence, it seems central to have a reflexive discussion, not only about how to apply the approach but also about what it may leave out. In that sense, I have merely simply tried to convey the kind of reservations an interpretive social scientist might have with MLG. I have not applied any fixed main evaluative criteria but rather tried to give a sense of the different kinds of research questions, epistemological presuppositions, and methodological preferences exhibit in research that might be relevant for the project.

6 I agree with one reviewer that it is unfair to say that MLG does not engage with power, and have amended the sentence. It can certainly be debated whether power is "black-boxes" in political ecology. I suppose the key issue is in different conceptualizations of power, leading to different understandings of how it might be identified and analyzed.

7 In fact, Pierre Bourdieu's notion of social capital (1986) precedes Putnam's discussion, and is considerably more sophisticated, but it has had little influence on development policy, probably because of its explicit consideration of politics and structural issues. Putnam's concept of social capital, and later applications such as Dasgupta and Serageldin (1999) and Woolcock and Narayan (2000) have been much debated and criticized on epistemological as well as political grounds (see Fine (2001), Bebbington et al (2004)).

8 I agree with one reviewer that it does not "deprive". It is simply that, since it is based on the (normative) assumption that synergy is good and conflict is bad, then it offers little help in understanding how conflict and contestation might also be generative for the achievement of goals (or the reconstruction of new and perhaps better goals). So it is somewhat one-sided.

9 The mandate of the literature review was to review approaches that might be interesting for the project, given its focus on multilevel governance, with a special emphasis on their conceptual, epistemological and methodological underpinnings, so the question of evidence is beyond the scope of the review. Reflexively, it is also worth emphasizing that what counts as evidence is not detached from theoretical and methodological assumptions and they wary widely across the literature I have surveyed. Finally -- of course MLG is important, but the literature review is premised on the notion that there are several other relevant approaches, which speak to core concerns of the project, though not in the same manner as MLG. One project member's comment suggest that MLG forms the baseline against which all these approaches should be evaluated. The review instead is premised on the notion that different perspectives might be equally important.
10 For a comment on the general 'strategy', please see the previous endnote. The literature discussed in this and following sections has different disciplinary origins and the language is therefore not identical with the one used in MLG approaches. It seems clear, however, that an interest in multiple changing forms of relationships between "state" and "society", including attentiveness to the politics and categories of governing, and an interest in the rationalities and concerns that guide efforts to develop states, is a) important for a project that aims to understand governance in relation to REDD+ and is b) not too dissimilar from the interests in MLG approaches in terms of themes of investigation. Of course, the aforementioned differences in epistemology, concepts and methods do remain but that is the reason for having the section.

11 A response by one reviewer here related to the point made by Stubbs and repeated by Jasanoff and Martello about the relationship between a normative commitment to promote certain kinds of governance and a descriptive/ analytical commitment to understand them. Descriptively/ analytically it cannot be assumed that a) current values of governance are shared or should be shared and b) that they are in fact good in the first place. That's empirical and analytical questions. However, normatively one might assume and promote certain values. Stubbs's and Jasanoff's critique is that the normative commitments of certain kinds of political science is assumed and unquestioned. I suppose the point is that if one is in fact committed to normative concepts of governance in a project that is about the scientific understanding of governance, then one needs to be reflexive and explicit about what it is one is committed to and why. In particular, this is the case if the value that is promoted is partnership, collaboration, mutual accountability etc. One version is that these are universal goods. But what they promote is of course attentiveness to different views and forms of knowledge. So what if, listening to these views and knowledges, one is made aware that partnership etc is not "their" concern, or that "they" have completely different ideas about their entailments? Is one then a promoter of partnership by ignoring those "wrong views" and engaging in consciousness-raising to make sure that other people learn to see these values like we do? Or by learning from foreign concerns how to redefine what is relevant as partnership etc?

Finally, it is definitely true that use of the "right words" is not the same as promoting these things in practice. But it is also the case that even if they are promoted in practice, their effects are often unforeseeable - because of their adaptation in different situations, their translations in specific contexts, and their interpretations by different constituents. So again, this is a call to get close to the contexts in which governance values are actually sought implemented so as to be able to understand their concrete effects. 
12 The imaginative blockage relates specifically to the kind of situation discussed in the last endnote. That is, that it is easy enough to call for the inclusion of different knowledges, but it is very hard to figure out how to take them seriously. One impediment identified by Jasanoff and Martello is the lack of governance forums, at multiple levels, where the knowledge of scientists and policy makers can be complemented or challenged by a broad range of other constituents. Another is the tendency to dismiss such voices precisely at the time where their views truly run counter to the established views of policy makers and scientists. Then they are likely to be seen as "just wrong" and dismissed. So the imaginative blockage refers first and foremost to the question of how to take seriously those that truly do not agree with framing of the governance problem, or its underpinning values, such that reflexive discussions about that framing and those values can itself be fed into the ongoing debate and be part of the solution.

13 The word "truly" is perhaps misleading but the point, I think, is to create forums that are not only participatory on paper, or formally, but in substance. And as one reviewer's comments make clear (e.g what if indigenous leaders are not democratic etc) this is a hard nut to crack. Even so, it is also not democratic to call for participation and then selectively exclude those that do not agree with one's views. If democratic participation is not to be solely'cosmetic' it is important to somehow find ways of involving and taking seriously such people. Correspondingly, it is important to pay attention to the situatedness of policy solutions and scientific framings of the problem. (for example, it is by no means consensual among scientists or policy-makers that REDD+ is the only or best solution, but now that REDD+ is in fact being implemented it seems there is not much need for continuously reflecting on its limits and problems, so it is already being black-boxed).

14 I agree that this was not precise enough and have amended somewhat. In particular the kind of critique levelled by Stubbs refers to the general conceptualization of MLG and not to specific studies such as Andersson and Ostrom. No doubt a broader selection of studies on polycentric theory would be worthwhile but time does not permit this and in any case there is already an "in-house" specialist involved with the project, so I am sure he is in a better position to refer other project members to relevant literature.

15 For the rationale behind talking about state-society relations, please see one of the previous endnotes. I agree that the notion of state-society is too dichotomous, and many of the authors who use the term agree too, making arguments akin to the one made by reviewers of this document. Polycentric governance theory definitely offers a way to study those relationships, but it would be necessary to also include and discuss other theories. The important question for the project probably relates to the question of what it means to study them in their particularities, and here there are no doubt disagreements. For example, whereas one reviewer of this document wrote in a previous comment that many studies tend to black box power, in contrast with polycentric governance theory, these scholars would probably respond that when polycentric governance theory turns historical and political relationships into variables and measures them based on e.g. number of interactions in meetings, this is an abstraction that does not speak to particularities.

16 I am not an expert on social network analysis. As I understand, social network analysis is an attempt to formalize the sociological interest in social relations, by defining individual actors as nodes linked through their relationships. One can then diagram these relationships and measure things like density and distance. In my estimate, the main problems with social network analysis pertain to its assumptions about relations and individuals. In a network diagram individual nodes are static, as are the links between them. Insofar as relations change, SNA has little to say about this, except by making another static diagram indicating a changing pattern. There is no emphasis on why and how they have changed, unless additional theories of action, practice, politics etc. are introduced. Likewise, SNA has no way of engaging with the qualities of relationship only their quantity. Indeed, it seems to have nothing to say about the changes of actors, since they are defined simply as nodes. For example, if in Agrawal's work, new environmental subjects are produced through governance initiatives, SNA offers no way of talking about the characteristics of those subjects or why they have changed; it can simply depict the fact that certain actors are now related to others from which they were previously unrelated. In that sense, the analytical merit of the method is somewhat unclear to me.

17 I agree that there are some important differences in emphasis here. The standard critique of ethnography is that it offers little by way of generalization, and I think this is also part of some critiques from reviewers of parts of this review. Reversely, the choices of variables in e.g. Andersson and Ostrom could be argued to not be sufficiently grounded in ethnographic understanding. Perhaps part of the iterative trick is to begin with ethnographic study to help choose the best possible variables and then use that for quantitative analysis, which can in turn feed into new ethnographic questions. 


\section{(b) Fund Norad}

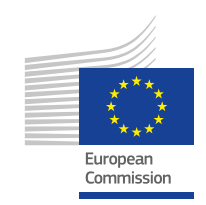

